\title{
Diversity of insect pollinators of Allium cepa L. (Liliaceae) and assessment of its impact on yields at Gazawa (Cameroon)
}

\author{
Georges Tchindebe ${ }^{*}$, Daniel Farda ${ }^{2}$, Dounia $^{3}$, Chantal Douka ${ }^{3}$, Ningatoloum Clautin ${ }^{4}$, Pharaon Mbianda Auguste ${ }^{5}$, \\ Tchuenguem Fohouo Fernand-Nestor ${ }^{6}$ \\ ${ }^{1}$ University of Douala, Institute of Fisheries and Aquatic Sciences, Department of Agronomy, P.O. Box 2701 Douala, Cameroon. \\ ${ }^{2}$ Department of Animal Production, School of Veterinary Medicine and Sciences, University of Ngaoundere, Ngaoundere, Cameroon. \\ ${ }^{3}$ Zoology Laboratory, Higher Teachers Training College, University of Yaounde I, Yaounde, Cameroon. \\ ${ }^{4}$ Department of Biological Sciences, University Adam Barka of Abéché, Abéché, Chad. \\ ${ }^{5}$ Laboratory of Zoology, Faculty of Science, University of Douala, Douala, Cameroon. \\ ${ }^{6}$ Laboratory of Applied Zoology, Faculty of Science, University of Ngaoundere, Ngaoundere, Cameroon.
}

\section{ARTICLE INFO}

Article history:

Received on: December 10, 2020

Accepted on: January 03, 2021

Available online: March 10, 2021

\section{Key words:}

Allium cepa,

Flowers,

Insects,

Pollination,

Yield.

\section{ABSTRACT}

To evaluate the impact of insect pollinators on pod, seeds, and seed yields of Allium cepa, the pollinating activities of flowering insects were studied in Maroua, during two dry seasons in 2017 and 2018 (November-April). Observations were made on 40-120 flowers per treatment. The flowers were subjected to different treatments: Treatment 1 (Free flowers); treatment 2 (bagged flowers); treatment 3 (castrated and free flowers); and treatment 4 (castrated and bagged flowers). About 320 flowers of A. cepa (Liliaceae) were observed in 2017 and 2018, respectively, for the diversity and frequency of insects' visits. For results, 6581 visits of 32 insect species distributed in seven orders were recorded on A. cepa flowers. The most dominating Hymenoptera observed was Apis mellifera followed by Lipotriches collaris with $24.49 \%$ and $12.43 \%$ of the total insect visits, respectively. The highest number of insect pollinators harvested in the flowers of this Liliaceae was between 8 and $9 \mathrm{~h}$. The studied insects have a positive impact on the yields of this plant. This positive impact of the pollinator insects on the yields was $81.09 \%, 87.79 \%$, and $96.54 \%$ in fructification rate, number of seeds pod, and percentage of normal seeds, respectively. The avoidance of pesticide treatment of plants during flowering could be a good management strategy to improve on plant yield.

\section{INTRODUCTION}

Onion, Allium cepa L., is originated from south and Central America [1]. It is grown in all country of the World [2] for its bulbs [1]. Onion has been used in various forms food as salads, as a raw or cooked vegetable, and as a condiment [3]. Its bulbs are a major vegetable source of Vitamin C and B, potassium, flavonoids, folic acid, calcium, and iron for man $[2,4]$. The production in Cameroon is estimated at 112441 tons, with 14.77 tons/ha. The far north region is the largest Producers of onion in the country $87.13 \%$ [5]. The production is low and the demand of bulbs is high in this country [6]. The main problem that growers are facing is how to obtain optimum seed yield to provide the good production of bulbs. Self-pollinating is generally not observing in the pollination of onion due to its protandrous nature [7]. The flowers of $A$. cepa produce nectar and pollen, which attracts insects [8]. To increasing the production of this plant in Maroua (Cameroon), it is important to investigate on the possibilities of flowering insects. It can

*Corresponding Author:

Georges Tchindebe, Department of Agronomy, University of Douala, Institute of Fisheries and Aquatic Sciences, P.O. Box 2701 Douala, Cameroon.

E-mail:watchinde@gmail.com be possible if local insects of $A$. cepa are known and exploited. The researchers conducted in Kenya, in India and in Cameroun revealed that onion does not produce good seed without pollinators [8-10]. During the collect of nectar and pollen on the flowers, the insects increase quantity and quality of the seeds [9]; it is now that the activities of pollinator insects on the flowers can vary with region [11]. The main objective of this research was to collect more data on the relations between $A$. серa and flowering insects. Specific objectives were (a) to determinate the diversity of flowering insects of $A$. cepa, (b) to evaluate the frequency of this insects on A. cepa flowers, and (c) to evaluate the impact of flowering insects on pollination and yield of this plant.

\section{MATERIALS AND METHODS}

\subsection{Site and Biological Materials}

The studies were conducted from November to April in 2017 and 2018, respectively, in the locality of Barza (Gazawa) Diamare division (Latitude $10^{\circ} 54.095 \mathrm{~N}$, longitude $14^{\circ} 12.892 \mathrm{E}$, and altitude 387 masl) in the Far North Region of Cameroon. Insect pollinators naturally present in the environment of the study represented the animal 
material. The plant material was represented by the bulbs of $A$. серa provided by the Institute of Agricultural Research for Development of Djarengol (Maroua).

\subsection{Methods}

\subsubsection{Planting and maintenance of culture}

At the beginning of each dry season (November) the experimental field was divided into 24 subplots of $1.5 \times 1.5 \mathrm{~m}^{2}$ each. Thirty onions bulbs were planted as nursery. About a period of 1 month, the nursery was transfer to the 24 subplots [8]. During the growing period, $5 \mathrm{~kg}$ of fertilizer (20-10-10) was applied on the plants. Plants were watered once a week. Weeding was done manually at the beginning of flowering until harvest.

\subsubsection{Diversity and frequency of flowering insects on the flowers of $A$. cepa}

On November 22, 2017, 24 subplots carrying 240 plants were labeled. Three subplots carrying 38 plants were left for open pollination (treatment 1), three subplots carrying the same number of plants like treatment 1 were protected with gauze mesh to prevent pollinator insects (treatment 2), 38 plants distributed in three subplots and only 40 flowers were destined to castration (treatment 3) and 38 plants carry by the last subplots and in the same subplot only 40 flowers were destined to be castrated and then protected with gauze mesh like treatment 2 (treatment 4). For castration, the stigmata were delicately remove using tongs.

The experiment was repeated in 2017. For each year, the pods were collected and the seeds were calculated.

The diversity of flowering insects that visited $A$. cepa flowers was appreciated; capture was done on flowers of treatment 1 and insects were conserved, described, and identified using the method of Borror and White [12], Eardley et al. [13], Eardley [14]. To know about the frequency of insect pollinators in the flowers of A. cepa, observations were done each day, from February 15 to March 16, 2017 and from February 12 to March 19, 2018. These observations were done during three slots per day ( $8-9 \mathrm{~h}, 12-13 \mathrm{~h}$, and $16-17 \mathrm{~h})$. The determination of the relative frequency of all insects that visited the $A$. cepa flowers was calculated using the formula: $F i=\{[(V i) / V I] \times 100\}(1)$, where $V i$ was the number of flowering insect $i$ on flowers of treatment 1 and $V I$ was the number of visits of all pollinator insects [11].

\subsubsection{Impact of flowering insects on the pollination of $A$. cepa}

The evaluation of the impact of flowering insects on the pollination of $A$. сеpa was done in the study and the frequency of insect visits was calculated. It was to record the number of times that the insect's body comes in contact with the anther of flower. This can indicate the possibility of flowering insect to participation in the self-pollination and cross-pollination [15]. To determine the different categories of pollinators, the regularity index (Id) was calculated using the formula: $I d=([P / 100] \times[f / 100])$, where $P$ and $f$ are the percentage of insect visits and the relative frequency of insect visits.

\subsubsection{Incidence of flowering insects on A. cepa yields}

Evaluation was based on the impact of visiting flowers on pollination, the impact of pollination on fructification of $A$. серa, and the comparison of yields (fruiting rate, mean number of seeds per pod, and percentage of well-developed seeds) of treatments 1, 2, 3, and 4.

- The fruiting rate due to the activity of insects $\left(F r_{i}\right)$ was calculated as follows: $F r_{i}=\left\{\left[\left(F r_{x}-F r_{y}\right) / F r_{x}\right] * 100\right\}$. Where $F r_{x}$ and $F r_{y}$ are the fruiting rates in each treatment.
- $\quad$ The fruiting rate $(F r)$ is: $F r=\left[\left(F_{2} / F_{l}\right) * 100\right]$. Where $F_{2}$ is the number of pods formed and $F_{1}$ the number of flowers initially set.

- The percentage of mean number of seeds per pod due to the activity of insects $(S p i)$ was calculated using the formula: $S p i=$ $\left\{\left[\left(S p_{x}-S p_{y}\right) / S p_{x}\right] * 100\right\}$. Where $S p_{x}$ and $S p_{y}$ are the percentages of seeds per pods in different treatments.

- The percentage of normal seeds due to the activity of insects (Nsi) was calculated as follows: $N s i=\left\{\left[\left(N s_{x}-N s_{y}\right) / N s_{x}\right] * 100\right\}$. Where $N s_{x}$ and $N s_{y}$ are the percentages of normal seeds in different treatments.

\subsubsection{Data analysis}

Data were analyzed using descriptive statistics, Student's $t$-test, correlation coefficient $(r)$, Chi-square $\left(\chi^{2}\right)$, ANOVA. We also used SPSS statistical software and Microsoft Excel.

\section{RESULTS}

\subsection{Diversity and Frequency of Entomofauna Insects of $\boldsymbol{A}$. cepa}

Among the 3350 and 3231 visits of 31 and 32 insect species counted on $A$. cepa flower in 2017 and 2018. For the two cumulated years; five orders of anthophilous insects were found on $A$. cepa flowers including: Diptera, Coleoptera, Hemiptera, Hymenoptera, and Lepidoptera [Table 1 and Figure 1]. Thirty two flowering insects were represented on A. cepa flowers: Constant species that include (Apis mellifera, Amegilla calens, Xylocopa olivacea, Lipotriches collaris, Chalicodoma rufipes, Belonogaster juncea, Xylocopa inconstans, Xylocopa nigrita, Lipotriches azarensis, Lasioglossum saegeri, Megachile bituberulata, Vespula vulgaris, and Lasioglossum atricrum) and accidental species (Pachnoda interrupta, Hypolimnas misippus, Aulacophora foveicollis, Danaus chrysippus, Eurema sp.1, Vanessa cardui, Catopsilia florella, Reduviidae (1sp.), Anoplocnemis curvipes, Ammophila sp., Philanthus triangulum, Camponotus flavomarginatus, Episyrphus balteatus, Chrysotoxum intermedium, Paragus borbonicus, Chrysomya chloropyga, Musca domestica, Coryna sp., and Mylabris sp.) [Table 2]. Flowering insects have been dynamic on the flowers of $A$. серa from 8 am to

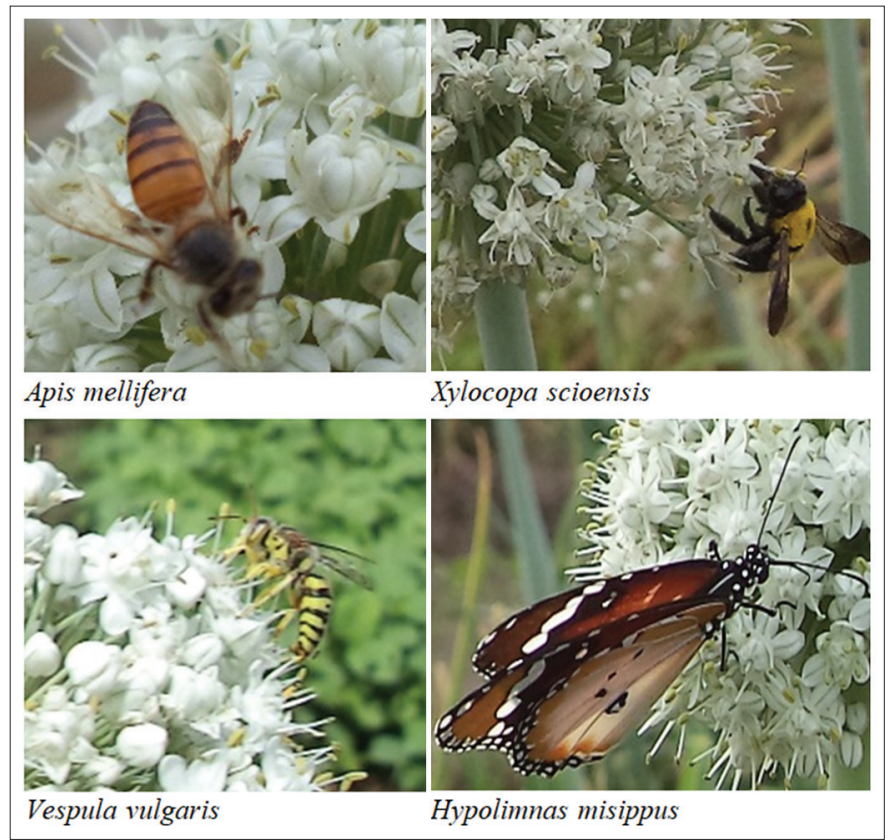

Figure 1: Some pollinators insects on flowers of Allium cepa. 
Tchindebe, et al.: Diversity of insect pollinators of Allium cepa 2021;9(2):85-92

Table 1: Diversity of flowering insects on Allium cepa in 2017 and 2018, number and percentage of visits of different insects.

\begin{tabular}{|c|c|c|c|c|c|c|c|c|}
\hline \multirow{2}{*}{$\begin{array}{l}\text { Insects } \\
\text { Order }\end{array}$} & \multirow[t]{2}{*}{ Family } & \multirow[t]{2}{*}{ Species } & \multicolumn{2}{|c|}{2017} & \multicolumn{2}{|c|}{2018} & \multicolumn{2}{|c|}{ Total } \\
\hline & & & $n_{1}$ & $P_{1}(\%)$ & $n_{2}$ & $P_{2}(\%)$ & $n_{t}$ & $P_{t}(\%)$ \\
\hline \multirow[t]{16}{*}{ Hymenoptera } & \multirow[t]{5}{*}{ Apidae } & Apis mellifera $(\mathrm{N}, \mathrm{P})$ & 773 & 23.07 & 839 & 25.97 & 1612 & 24.49 \\
\hline & & Amegilla calens $(\mathrm{N})$ & 201 & 6.00 & 153 & 4.74 & 354 & 5.38 \\
\hline & & Xylocopa olivacea $(\mathrm{N})$ & 179 & 5.34 & 418 & 12.94 & 597 & 9.07 \\
\hline & & Xylocopa inconstans $(\mathrm{N})$ & 142 & 4.24 & 257 & 7.95 & 399 & 6.06 \\
\hline & & Xylocopa nigrita $(\mathrm{N})$ & 187 & 5.58 & 49 & 1.52 & 236 & 3.59 \\
\hline & \multirow[t]{4}{*}{ Halictidae } & Lipotriches collaris $(\mathrm{P})$ & 321 & 9.58 & 497 & 15.38 & 818 & 12.43 \\
\hline & & Lipotriches azarensis (P) & 108 & 3.22 & 45 & 1.39 & 153 & 2.32 \\
\hline & & Lasioglossum atricrum $(\mathrm{P})$ & 98 & 2.93 & 67 & 2.07 & 165 & 2.51 \\
\hline & & Lasioglossum saegeri (P) & 76 & 2.27 & 98 & 3.03 & 174 & 2.64 \\
\hline & \multirow[t]{2}{*}{ Megachilidae } & Megachile bituberulata (P) & 44 & 1.31 & 51 & 1.58 & 95 & 1.44 \\
\hline & & Chalicodoma rufipes $(\mathrm{N})$ & 276 & 8.24 & 170 & 5.26 & 446 & 6.78 \\
\hline & \multirow[t]{2}{*}{ Vespidae } & Belonogaster juncea $(\mathrm{N})$ & 114 & 3.40 & 98 & 3.03 & 212 & 3.22 \\
\hline & & Vespula vulgaris $(\mathrm{N})$ & 19 & 0.57 & 34 & 1.05 & 53 & 0.81 \\
\hline & \multirow[t]{2}{*}{ Sphecidae } & Ammophila sp. (N) & 19 & 0.57 & 33 & 1.02 & 52 & 0,79 \\
\hline & & Philanthus triangulum (N) & 67 & 2.00 & 16 & 0.50 & 83 & 1,26 \\
\hline & Formicidae & Camponotus flavomarginatus (po) & 153 & 4.57 & 111 & 3.44 & 264 & 4,01 \\
\hline \multirow[t]{5}{*}{ Diptera } & \multirow[t]{3}{*}{ Syrphidae } & Episyrphus balteatus $(\mathrm{N})$ & 91 & 2.72 & 5 & 0.15 & 96 & 1,46 \\
\hline & & Chrysotoxum intermedium (N) & 34 & 1.01 & 13 & 0.40 & 47 & 0,71 \\
\hline & & Paragus borbonicus (P) & 58 & 1.73 & 44 & 1.36 & 102 & 1,55 \\
\hline & Calliphoridae & Chrysomya chloropyga $(\mathrm{N})$ & 41 & 1.22 & 31 & 0.96 & 72 & 1.09 \\
\hline & Muscidae & Musca domestica $(\mathrm{N})$ & 13 & 0.39 & 6 & 0.19 & 19 & 0.29 \\
\hline \multirow[t]{3}{*}{ Coleoptera } & \multirow[t]{2}{*}{ Meloidae } & Coryna sp. (P) & 77 & 2.30 & 9 & 0.28 & 86 & 1.31 \\
\hline & & Mylabris sp. (P) & 43 & 1.28 & 21 & 0.65 & 64 & 0.97 \\
\hline & Cetoniidae & Pachnoda interrupta (P) & 11 & 0.33 & 64 & 1.98 & 75 & 1.14 \\
\hline \multirow[t]{6}{*}{ Lepidoptera } & \multirow[t]{2}{*}{ Chrysomelidae } & Aulacophora foveicollis (P) & 8 & 0.24 & 17 & 0.53 & 25 & 0.38 \\
\hline & & Eurema sp.1 (P) & 70 & 2.09 & 18 & 0.56 & 88 & 1.34 \\
\hline & \multirow[t]{2}{*}{ Pieridae } & Vanessa cardui $(\mathrm{N})$ & 47 & 1.40 & 19 & 0.59 & 66 & 1.00 \\
\hline & & Catopsilia florella $(\mathrm{N})$ & 66 & 1.97 & 40 & 1.24 & 106 & 1,61 \\
\hline & \multirow[t]{2}{*}{ Nymphalidae } & Danaus chrysippus $(\mathrm{P})$ & 10 & 0.30 & 4 & 0.12 & 14 & 0.21 \\
\hline & & Hypolimnas misippus $(\mathrm{N})$ & 2 & 0.06 & 1 & 0.03 & 3 & 0.05 \\
\hline \multirow[t]{3}{*}{ Hemiptera } & Reduviidae & $(1 \mathrm{sp}).(\mathrm{P})$ & - & - & 2 & 0.06 & 2 & 0.03 \\
\hline & \multirow[t]{2}{*}{ Pentatomidae } & Anoplocnemis curvipes (P) & 2 & 0.06 & 1 & 0.03 & 3 & 0.05 \\
\hline & & & 3350 & 100 & 3231 & 100 & 6581 & 100 \\
\hline
\end{tabular}

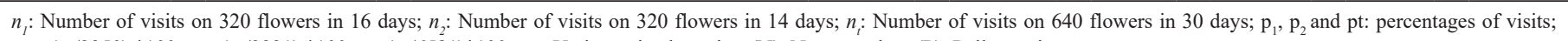
$\mathrm{p}_{1}=\left(\mathrm{n}_{1} / 3350\right) * 100 ; \mathrm{p}_{2}=\left(\mathrm{n}_{2} / 3231\right) * 100 ; \mathrm{pt}=(\mathrm{nt} / 6581) * 100 ; \mathrm{sp} .:$ Undetermined species; $(\mathrm{N})$ : Nectar gather; $(\mathrm{P})$ : Pollen gather

17 pm, with a peak of visits between 8 and 9 am in 2017 and 2018 [Table 3].

\subsection{Impact of Flowering Insects on Pollination of $\boldsymbol{A}$. cepa}

Three categories of pollinators were observed on flowers of $A$. cepa in 2017 and 2018 [Table 4]:

- Major pollinators (Id $>0.05$ and/or $P>50 \%$ ) A. mellifera, A. calens, $X$. olivacea, $X$. inconstans, and $L$. collaris.

- Minor pollinators $(0,05 \leq I d<0.001$ and/or $50 \leq P<25)$ $X$. nigrita, L. azarensis, $L$. atricrum, $L$. saegeri, M. bituberulata, C. rufipes, B. juncea, V. vulgaris, Ammophila sp., P. triangulum, C. flavomarginatus, E. balteatus, C. intermedium, P. borbonicus, C. chloropyga, M. domestica, Coryna sp., Mylabris sp., P. interrupta, Eurema sp.1, V. cardui, and C. florella.
- Occasional pollinators $(I d<0.001$ and/or $p<25) H$. misippus, A. foveicollis, D. chrysippus, Reduviidae (1sp.), and A. curvipes.

\subsection{Impact of Anthophilous Flowering Insects on Yield of A. cepa}

During foraging behavior on flower of $A$. серa, flowering insects always shook flowers and are regularly in contact with the anthers and stigma $(P=90.10 \%)$, increasing pollination possibility of A. cepa fruiting rate, number of seeds, and proportion of normal seeds [Table 5].

a - The comparison of the fruiting rate showed that the difference was very highly significant between treatments in $2017(F=16.67, d f=3$, $P<0.001)$ and in $2018(F=13.12, d f=3, P<0.001)$. The difference observed was highly significant between fruiting rate of free opened 
Table 2: Distribution of flowering insects according to the seasonal frequency of visits in 2017 and 2018.

\begin{tabular}{|c|c|c|c|c|c|c|c|}
\hline \multirow[t]{2}{*}{ Insects } & \multicolumn{2}{|c|}{2017} & \multicolumn{2}{|c|}{2018} & \multicolumn{2}{|c|}{ Total } & \multirow[t]{2}{*}{ Category of insects } \\
\hline & $n 1$ & $f_{1}(\%)$ & $n_{2}$ & $f_{2}(\%)$ & $n_{1,2}$ & $f_{1.2}(\%)$ & \\
\hline Apis mellifera & 16 & 100 & 14 & 100 & 30 & 100 & \multirow[t]{8}{*}{ Constant species ( $\mathrm{f} \geq 50 \%$ ) } \\
\hline Xylocopa olivacea & 11 & 68.7 & 14 & 100 & 25 & 83.3 & \\
\hline Lipotriches collaris & 16 & 100 & 14 & 100 & 30 & 100 & \\
\hline Chalicodoma rufipes & 13 & 81.2 & 11 & 100 & 24 & 80 & \\
\hline Xylocopa inconstans & 8 & 50 & 8 & 57.14 & 16 & 53.33 & \\
\hline Xylocopa nigrita & 9 & 56.25 & 9 & 64.28 & 18 & 60 & \\
\hline Lipotriches azarensis & 10 & 62.5 & 11 & 78.57 & 21 & 70 & \\
\hline Lasioglossum saegeri & 9 & 56.25 & 7 & 50 & 16 & 53.33 & \\
\hline Hypolimnas misippus & 1 & 6.25 & 2 & 40 & 3 & 10 & \multirow{13}{*}{ Accidental species $(\mathrm{f}<25 \%)$} \\
\hline Aulacophora foveicollis & 1 & 6.25 & 2 & 20 & 3 & 10 & \\
\hline Danaus chrysippus & 2 & 12.5 & 3 & 40 & 5 & 16.6 & \\
\hline Eurema sp.1 & 3 & 18.75 & 6 & 42.86 & 9 & 30.00 & \\
\hline Vanessa cardui & 3 & 18.75 & 5 & 35.71 & 8 & 26.67 & \\
\hline Catopsilia florella & 4 & 25 & 5 & 35.71 & 9 & 30.00 & \\
\hline Reduviidae (1sp.) & 1 & 6.25 & 3 & 21.43 & 4 & 13.33 & \\
\hline Anoplocnemis curvipes & 3 & 18.75 & 4 & 28.57 & 7 & 23.33 & \\
\hline Ammophila sp. & 2 & 12.5 & 4 & 28.57 & 6 & 20.00 & \\
\hline Musca domestica & 3 & 18.75 & 2 & 14.29 & 5 & 16.67 & \\
\hline Coryna sp. & 2 & 12.5 & 2 & 14.29 & 4 & 13.33 & \\
\hline \multirow[t]{2}{*}{ Mylabris sp. } & 1 & 6.25 & 2 & 14.29 & 3 & 10.00 & \\
\hline & 16 & 100 & 14 & 100 & 30 & 100 & \\
\hline
\end{tabular}

$n_{1}$ : Number of observation days in 2017. $n_{2}$ : Number of observation days in 2018. $n_{1,2}:$ Number of observation days in 2017 and in $2018 . f_{i}$ : Relative frequency of visits in 2017. $f_{2}$ : Relative frequency of visits in 2018. $f_{1,2}$ : Relative frequency of visits in 2017 and in 2018.

flowers (treatment 1) and that of bagged flowers (treatment 2) $\left(\chi^{2}=161.96, d f=1, P<0.001\right)$, free flowers (treatment 1$)$ and castrated and bagged flowers (treatment 4$)\left(\chi^{2}=113.17, d f=1, P<0.001\right)$. The difference observed was not significant between fruiting rate of free opened flowers (treatment 1) and castrated and opened flowers (treatment 3) $\left(\chi^{2}=0.11, d f=1, P>0.05\right)$ in 2017 and $\left(\chi^{2}=0.11\right.$, $d f=1, P>0.05)$ in 2018 . In the $2^{\text {nd }}$ year, the same results were $\left(\chi^{2}=138.76, d f=1, P<0.001\right)$ and $\left(\chi^{2}=101.44, d f=1, P<0.001\right)$. The fruiting rate of treatment 1 and 3 was higher than treatments 2 and 4 in 2017 and in 2018. The fruiting rate due to the action of insects was 80.51 and $81.67 \%$ in 2017 and 2018, respectively. For the two cumulated years, the fructification rate due to the influence of insects was $81.09 \%$. b - The comparison of the mean number of seeds per pod showed that the difference was highly significant between treatments in 2017 $(F=9.35, d f=3, P<0.001)$ and in $2018(F=8.72, d f=3, P<0.001)$. The difference observed was highly significant between mean number of seeds per pod in treatment 1 and treatment $2(t=29.41, d f=133$, $P<0.001)$, the same observation was fund in treatment 1 and treatment $3(t=9.12, d f=172, P<0.001)$, and the difference observed was significant between mean number of seeds per pod in treatment 1 and treatment $4(t=22.21, d f=130, P<0.001)$ in the $1^{\text {st }}$ year. In the $2^{\text {nd }}$ year, the difference was significant between mean number of seeds per pod in treatment 1 and treatment $2(t=29.41, d f=133, P<0.001)$ and between treatment 1 and treatment $3(t=14.12, d f=176, P<0.001)$. The mean number of seeds per pod in treatment 1 was higher than treatments 2, 3, and 4 in 2017 as well as in 2018. The mean number 
Table 3: Variation of number of visits on flowers of Allium cepa giving to the daily time.

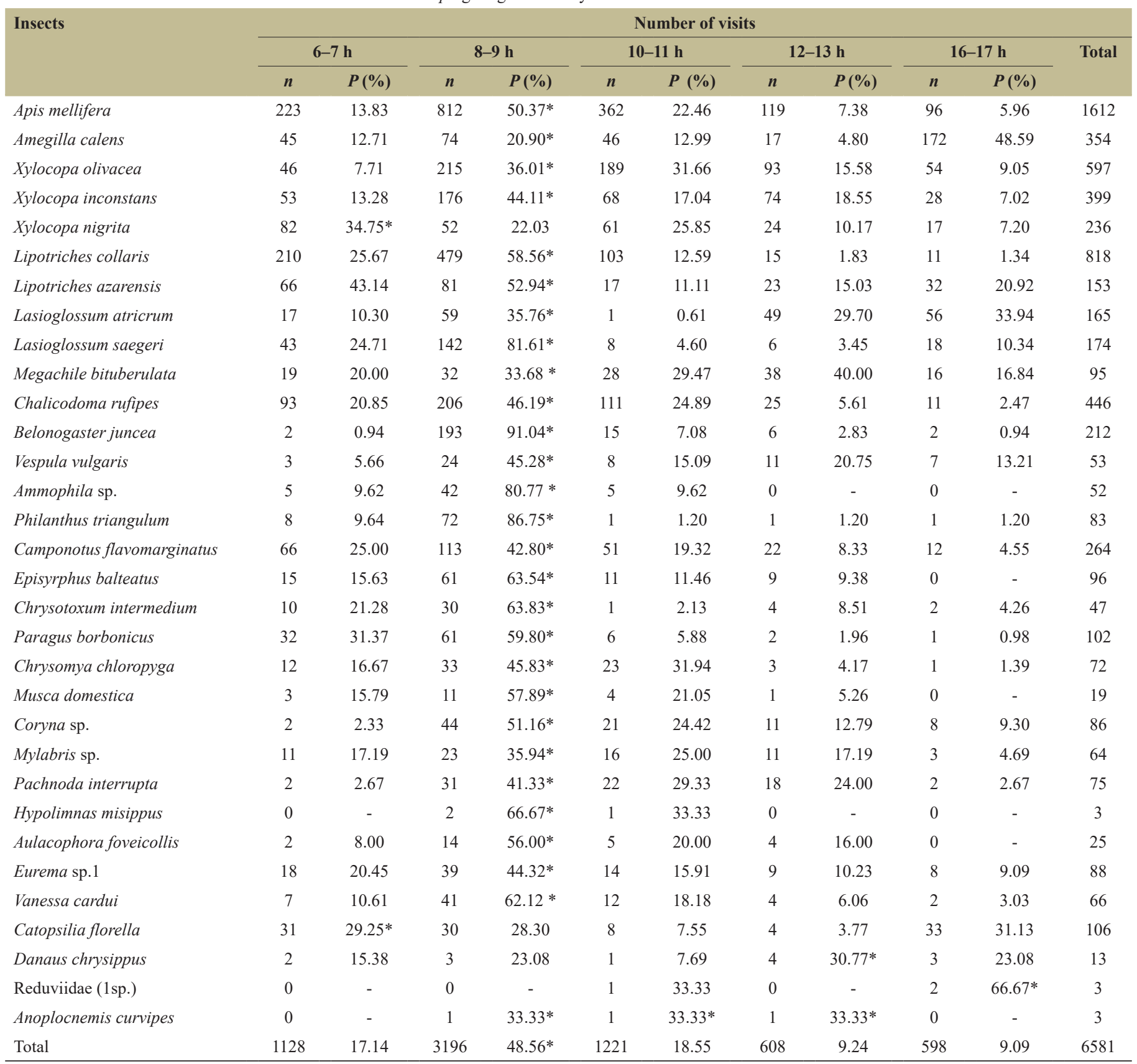

$n$ : number of visits ; $p(\%)$ : percentage of visits ; $(*)$ : peak of visits

of seeds per pod due to the action of insects was $85.59 \%$ in 2017 and $90 \%$ in 2018 . For the two cumulated years, the mean number of seeds per pod due to the influence of insects was $87.79 \%$.

c - By comparing the percentage of normal seeds, we obtained that the difference was highly significant between treatments in $2017\left(\chi^{2}=216\right.$, $d f=2, P<0.001)$ and in $2018\left(\chi^{2}=344.19, d f=2, P<0.001\right)$. The difference observed was highly significant between the percentage of normal seeds of in treatment 1 and treatment $2\left(\chi^{2}=91.43, d f=1\right.$, $P<0.001)$, the same observation was fund in treatment 1 and treatment $3\left(\chi^{2}=19.87, d f=1, P<0.001\right)$ in the $1^{\text {st }}$ year. In the $2^{\text {nd }}$ year, the results were $\chi^{2}=129.68, d f=1, P<0.001$ in treatment 1 and treatment 2 and $\chi^{2}=221.13, d f=1, P<0.001$ in treatment 1 and treatment 3 . The percentage of normal seeds of treatment 1 was higher than treatments 2 and 3 in 2017 as well as in 2018 . The mean percentage of normal seeds due to the action $\mathrm{f}$ insects was $97.02 \%$ in 2017 and $96.07 \%$ in 2018 . For the two cumulated years, the mean number of seeds per pod due to the influence of insects was $96.54 \%$.

\section{DISCUSSION}

In Maroua during our observation period the must flowering insects visited the $A$. cepa flowers is representing by the order of the Hymenoptera witch $86.81 \%$ of all visits; in Cameroun $[8,10]$, in India [3] found that the Hymenoptera were most abundant insects on the flowers of this Liliaceae witch respectively 60 and $83 \%$. Some particular pollinators insect's like A. mellifera was the main 
Table 4: Regulator index, number, and percentage of visits with stigmata contact of flower of Allium cepa.

\begin{tabular}{|c|c|c|c|c|c|c|}
\hline \multirow[t]{2}{*}{ Insects } & \multirow{2}{*}{$\frac{2017}{I d_{1}}$} & \multirow{2}{*}{$\begin{array}{c}2018 \\
I d_{2}\end{array}$} & \multirow{2}{*}{ 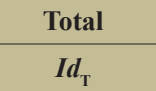 } & \multicolumn{3}{|c|}{ NPV } \\
\hline & & & & $S V$ & $n$ & $P(\%)$ \\
\hline Apis mellifera & 0.2307 & 0.2597 & 0.2449 & 1612 & 1612 & 100.00 \\
\hline Xylocopa olivacea & 0.0366858 & 0.1294 & 0.0755531 & 597 & 597 & 100.00 \\
\hline Xylocopa inconstans & 0.0424 & 0.0795 & 0.0606 & 399 & 399 & 100.00 \\
\hline Xylocopa nigrita & 0.0453096 & 0.0152 & 0.02872 & 236 & 236 & 100.00 \\
\hline Lipotriches azarensis & 0.0161 & 0.00794246 & 0.01237256 & 153 & 153 & 100.00 \\
\hline Lasioglossum atricrum & 0.01648125 & 0.01330596 & 0.01506 & 165 & 165 & 100.00 \\
\hline Lasioglossum saegeri & 0.0141875 & 0.02380671 & 0.01848 & 174 & 174 & 100.00 \\
\hline Megachile bituberulata & 0.00736875 & 0.0079 & 0.00767952 & 95 & 95 & 100.00 \\
\hline Philanthus triangulum & 0.00125 & 0.002 & 0.00126 & 83 & 83 & 100.00 \\
\hline Camponotus flavomarginatus & 0.00285625 & 0.00688 & 0.00401 & 264 & 264 & 100.00 \\
\hline Episyrphus balteatus & 0.0034 & 0.0006 & 0.0024236 & 96 & 96 & 100.00 \\
\hline Chrysotoxum intermedium & 0.00189375 & 0.0017144 & 0.00213 & 47 & 47 & 100.00 \\
\hline Paragus borbonicus & 0.00324375 & 0.00485656 & 0.00413385 & 102 & 102 & 100.00 \\
\hline Chrysomya chloropyga & 0.00305 & 0.00342816 & 0.00327 & 72 & 72 & 100.00 \\
\hline Musca domestica & 0.00024375 & 0.00040717 & 0.00038657 & 19 & 19 & 100.00 \\
\hline Coryna sp. & 0.0043125 & 0.00079996 & 0.00305623 & 86 & 67 & 77.91 \\
\hline Mylabris sp. & 0.0016 & 0.00185705 & 0.00194 & 64 & 52 & 81.25 \\
\hline Danaus chrysippus & 0.00050625 & 0.00017148 & 0.0003334 & 13 & 10 & 76.92 \\
\hline Reduviidae (1sp.) & 0.0000375 & 0.00008574 & 0.00006665 & 3 & 2 & 66.67 \\
\hline Anoplocnemis curvipes & 0.0000375 & 0.00004287 & 0.00005 & 3 & 2 & 66.67 \\
\hline
\end{tabular}

$I d=(P / 100) \times(f / 100) ; P$ : Percentage of visits; $f$ : Relative frequency of visits; $S V$ : Study visits; $N P V$ : Number and percentage of visits with stigmata contact; n: Number of visits with contact; $P(\%)$ : Percentage of visits with contact.

Table 5: Fruiting rate, number of seed per pod, and percentage of normal seeds according to different treatments of Allium cepa in 2017 and 2018.

\begin{tabular}{|c|c|c|c|c|c|c|c|c|c|c|}
\hline \multirow[t]{2}{*}{ Treatments } & \multirow[t]{2}{*}{ Year } & \multirow[t]{2}{*}{ NF } & \multirow[t]{2}{*}{ NPd } & \multirow[t]{2}{*}{ FR } & \multicolumn{3}{|c|}{$\mathrm{Sd} / \mathrm{Pd}$} & \multirow[t]{2}{*}{ TSd } & \multirow[t]{2}{*}{ NSd } & \multirow[t]{2}{*}{$\% \mathrm{NSd}$} \\
\hline & & & & & $n$ & $m$ & $s$ & & & \\
\hline $\mathrm{T}_{1}(\mathrm{Fr})$ & 2017 & 120 & 118 & 98.33 & 118 & 3.78 & 0.21 & 411 & 403 & 98.05 \\
\hline $\mathrm{T}_{2}(\mathrm{Ba})$ & & 120 & 17 & 14.16 & 17 & 1.11 & 0.17 & 32 & 12 & 37.50 \\
\hline $\mathrm{T}_{3}(\mathrm{COp})$ & & 60 & 56 & 93.33 & 56 & 3.44 & 0.14 & 128 & 113 & 88.28 \\
\hline $\mathrm{T}_{4}(\mathrm{CBa})$ & & 60 & 14 & 23.33 & 24 & 3.17 & 0.18 & 23 & 9 & 39.13 \\
\hline $\mathrm{T}_{1}(\mathrm{Fr})$ & 2018 & 120 & 120 & 100 & 120 & 3.91 & 0.23 & 421 & 408 & 96.91 \\
\hline $\mathrm{T}_{2}(\mathrm{Ba})$ & & 120 & 22 & 18.33 & 22 & 2.15 & 0.22 & 45 & 16 & 35.55 \\
\hline $\mathrm{T}_{3}(\mathrm{COp})$ & & 60 & 58 & 96.66 & 58 & 3.74 & 0.24 & 124 & 118 & 95.16 \\
\hline $\mathrm{T}_{4}(\mathrm{CBa})$ & & 60 & 10 & 16.66 & 30 & 2.45 & 0.38 & 26 & 8 & 30.76 \\
\hline
\end{tabular}

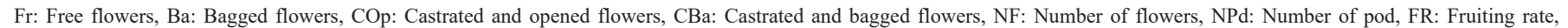
Sd/Pd: Seeds per pod, TSd: Total of seeds, NSd: Normal seeds, \%NSd: Percentage of normal seeds. 
Tchindebe, et al.: Diversity of insect pollinators of Allium cepa 2021;9(2):85-92

floral visitor of $A$. серa during the flowering periods; our result confirms other findings reported by [16] on $A$. серa in India, by Venkatesh et al. [17] and Kasina et al. [18]. The most common insect pollinator in onion fields is the honeybee [19]. Moreover, in other parts of the world such as the India [20,21], the bees A. florea have been reported as the main floral visitors of this crop. Many others results Ahmed and Abdalla, Mayer and Lunden, Tolon and Duman, [22-24] clearly showed that the genus Apis was found to be the most abundant on onion flowers. Through the abundance and diversity of pollinator fluctuate depending on the areas [25]. The peak of the activity of flowering insects on A. серa flowers was located between 08am and $09 \mathrm{am}$, which could be associated with the highest availability period of nectar on A. cepa flowers. The studies conducted by Asif et al. [26] showed the same results in Pakistan. For this research, it has been indicated that $A$. mellifera, $X$. olivacea, and $L$. collaris offer benefits to pollination management of A. cepa. During the collection of nectar and pollen on each flower, the bee regularly come into contact with the stigma (100\%) and they have the most important regulator index $(I d>0.05)$. The significant contribution of insect pollinators in pods and seed yield of $A$. сеpa is in agreement with the similar findings in India [27], in the far north Region of Cameroon in Maroua $[8,10]$ and in Pakistan [28]. The impact of insect pollinators of to A. cepa production was significantly higher than that of protected flowers. The weight of some insect pollinators such as $A$. mellifera, A. calens, $X$. olivacea, L. collaris, C. rufipes, $B$. juncea, $X$. inconstans, $X$. nigrita, and $L$. azarensis played a positive role during nectar and or pollen collection. The pollinator insects shook flowers and could ease the liberation of pollen by anthers for the optimal occupation of the stigma. The higher productivity of pods, seeds, and normal seeds in the treatment with unlimited visits when compared to treatment with protected flowers showed that pollinator insect visits were effective in increasing cross-pollination. Our results confirmed those of [29] who revealed that $A$. cepa flowers set little pods in the absence of insect pollinators. Similar observations done in Poland [30], the presence of honeybees and other pollinating insects is needed for a good setting and high seed yield. According to Zdzislaw et al. [31], self-pollination is not possible in onion; therefore, pollen must reach from another flower of the same or different plant. The same author showed that onion does not produce seed if insects do not pollinate flowers. In commercial production of seed, the industry depends on the honeybee for pollination [23].

\section{CONCLUSION}

This study revealed that the flowers of the variety of $A$. cepa studied attracted insect pollinators and the plant obtained profits from the pollination by those insects. A. mellifera is the most frequent pollinator followed by L. collaris which harvested nectar and pollen. By comparison, of pods, and seeds, between unprotected flowers and protected flowers, it was observed that insect pollinators contribute positively in increasing pods, seed, and seed weight yields as well as seed quality. It is suggested to avoid pesticide treatment of plants during flowering for a good management strategy to improve on plant yield.

\section{AUTHOR CONTRIBUTIONS}

All authors made substantial contributions to conception and design, acquisition of data, or analysis and interpretation of data; took part in drafting the article or revising it critically for important intellectual content; agreed to submit to the current journal; gave final approval of the version to be published; and agree to be accountable for all aspects of the work. All the authors are eligible to be an author as per the international committee of medical journal editors (ICMJE) requirements/guidelines.

\section{FUNDING}

There is no funding to report.

\section{CONFLICTS OF INTEREST}

The authors report no financial or any other conflicts of interest in this work.

\section{ETHICAL APPROVALS}

Not applicable.

\section{PUBLISHER'S NOTE}

This journal remains neutral with regard to jurisdictional claims in published institutional affiliation.

\section{REFERENCES}

1. Graham PH, Ranalli P. Common bean (Phaseolus vulgaris L.). Field Crops Res 1997;53:131-46.

2. Albatar N. Etude Comparative des Procédés de Séchage Couplés à la Texturation par Détente Instantanée Contrôlée DIC, en Termes de Cinétique et de Qualité Nutritionnelle. France: Applications A la valorisation Des Déchets Agro-industriels. Thèse, Université de La Rochelle; 2010. p. 191.

3. Devi S, Gulati R, Tehri K, Asha A. Diversity and abundance of insect pollinators on Allium cepa L. J Entomol Zool Stud 2014;2:34-8.

4. Abrol DP. Pollination Biology: Biodiversity Conservation and Agricultural Production. New York: Springer; 2014. p. 151.

5. Magalie C, Woin N, Essang T. In: Jean-Yves J, Boukar LS, editors. L'oignon, une Production en Plein Essor au Nord-Cameroun. Christian Floret, CIRAD-PRASAC; 2003. p. 8.

6. MINADER. Annuaire des statistiques du secteur agricole, Campagnes 2009 and 2010. direction des enquetes et statistiques. AgriStat Cameroun 2012;17:123.

7. Sihag RC. Floral biology, melittophily and pollination ecology of cultivated umbelliferous crops. In: Varghese TM, editor. Recent Advances in Pollen Research. New Delhi: Allied Publishers; 1985. p. 269-76.

8. Tchindebe G, Tchuenguem FF. Foraging and pollination activity of Apis mellifera adansonii Latreille (Hymenoptera: Apidae) on flowers of Allium cepa L. (Liliaceae) at Maroua, Cameroon. Int J Agron Agric Res 2014;5:139-53.

9. Chandel RS, Thakur RK, Bhardwaj NR, Pathania N. Onion seed crop pollination: A missing dimension in mountain horticulture. Acta Hortic 2004;631:79-86.

10. Djonwangwe D, Pando JB, Tchuenguem FF. Diversité des insectes floricoles de Allium cepa L. 1753 (Liliaceae) à Dogba et à Gazawa (Diamaré, Extrême-Nord, Cameroun). J Chem Biol Phys Sci 2019;9:281-95.

11. Tchuenguem FF. Activité de Butinage et de Pollinisation d'Apis mellifera adansonii Latreille (Hymenoptera: Apidae, Apinae) sur les Fleurs de Trois Plantes à Ngaoundéré (Cameroun): Callistemon rigidus (Myrtaceae), Syzygium guineense var. macrocarpum (Myrtaceae) et Voacanga africana (Apocynaceae). Thèse de Doctorat d'Etat, Université de Yaoundé I; 2005. p. 103.

12. Borror DJ, White RE. Les Insectes de l'Amérique du Nord (au Nord du Mexique). Broquet: La Prairie; 1991. p. 408.

13. Eardley CD, Kuhlmann M, Pauly A. Les genres et sous-genres 
d'abeilles de l'Afrique subsaharienne. ABC Taxa 2010;9:152.

14. Pauly A. Hymenoptera apoidea du gabon. Ann Sci Zool 1998;282:1-121.

15. Delaplane KS, Dag A, Danka RG, Freitas BM, Garibaldi LA, Goodwin RM, et al. Standard methods for pollination research with Apis mellifera. J Apic Res 2013;52:1-28.

16. Kumar J, Gupta JK. Nectar sugar production and honey bee foraging activity in three species of onion (Allium species). Apidologie 1993;24:391-6.

17. Venkatesh H, Reddy MS, Venkateshalu V, Hanumanthaswamy BC, Lingamurthi KR, Ravikumar B, et al. Pollinator diversity, abundance and their stay time in onion, Allium cepa L. J Entomol Zool Studs 2019;7:158-61.

18. Kasina M, Kraemer M, Martius C, Wittmann D. Diversity and activity density of bees visiting crop flowers in Kakamega, Western Kenya. J Apic Res Bee World 2009b;48:134-9.

19. Nye WP, Shahsha NS, Campbell WF, Hamson AR. Insect Pollination and Seed Set of Onions (Allium cepa L.). Vol. 61. The Utah Agricultural Experiment Station; 1973. p. 275-78.

20. Abrol DP. Megascolia flavifrons an unusual pollinator of onion flowers. Adv Pollen Spore Res 2010a;28:51-6.

21. Abrol DP. Foraging behaviour of Apis florea F., an important pollinator of Allium cepa L. J Apic Res Bee World 2010b;49:318-25.

22. Ahmed IH, Abdalla AA. The role of honeybees as pollinators on onion (Allium cepa L.) seed production. Acta Hortic 1984;143: 127-32.

23. Mayer DF, Lunden JD. Honey bee management and wild bees for pollination of hybrid onion seed. Acta Hortic 2001;561:275-78.

24. Tolon B, Duman Y. The Effect of Pollination by Honeybee (Apis mellifera) on Onion (Allim cepa) Seed Production and Quality. 38 Apimondia International Apicultural Congress; 2003. p. 554.

25. Roubik DW. Pollination system stability in tropical America. Conserv Biol 2000;14:1235-6.

26. Asif S, Shafqat S,. Asad M. Pollinator community of onion (Allium cepa L.) and its role in crop reproductive success. Pak J Zool 2008;40:451-6.

27. Ajay PT. Comparative study of cross-pollination on onion by Apis melifera and Apis indica. Life Sci Int Res J 2016;3:29-32.

28. Mohammad SM, Shazia R, Shahid N, Ghulam S. Comparative performance of honeybees (Apis mellifera $\mathrm{L}$ ) and blowflies (Phormia terronovae) in onion (Allium cepa L.) seed setting. J Agric Res 2011;49:49-56.

29. Lesley C, Ockendon DJ. Protandry and sequence of flower opening in the onion (Allium cepa L.). New Phytol 1978a;81:419-28.

30. Woyke H. Some Aspects of the Role of the Honeybee in Onion Seed Production in Poland. ISHS Acta Horticultural 111. Poland: Symposium on Vegetable and Flower Seed Production; 1981.

31. Zdzislaw W, Giejdasz J, Proszynski G. Effect of pollination on onion seeds under isolation by the mason bee (Osmia rufa L.) Apoidea, Megachillidae) on the setting and quality of obtained seeds. J Apic Sci 2004;48:35-41.

How to cite this article:
Tchindebe G, Farda D, Dounia, Douka C, Clautin N, Auguste PM, Fernand-
Nestor TF. Diversity of insect pollinators of Allium cepa L. (Liliaceae)
and assessment of its impact on yields at Gazawa (Cameroon). J App Biol
Biotech. 2021;9(2):85-92. DOI: 10.7324/JABB.2021.9208

